\title{
Interplay of Oxidative Stress and Nitric Oxide Synthase Gene Expression on Cardiovascular Responses in Preeclampsia
}

\section{Interação do estresse oxidativo e da expressão dos genes das óxido nítrico sintases nas respostas cardiovasculares na pré-eclâmpsia}

\author{
Anita Herur ${ }^{1,20}$ Manjunatha Aithala10 ${ }^{10}$ Kusal K. Das ${ }^{10}$ Ashalata Mallapur ${ }^{20}$ Rajat Hegde ${ }^{3(0)}$
}

Suyamindra Kulkarni ${ }^{10}$

\footnotetext{
${ }^{1}$ Department of Physiology, Shri B. M. Patil Medical College, Hospital and Research Centre, BLDE (Deemed to be University), Vijayapur586103, Karnataka, India

2 Department of Physiology and OBG, S. Nijalingappa Medical college, Bagalkot-587103, Karnataka, India

${ }^{3}$ Karnataka Institute for DNA Research (KIDNAR), Dharwad-580003,

Karnataka, India
}

Rev Bras Ginecol Obstet 2022;44(3):214-219.

\begin{abstract}
Address for correspondence Anita Herur, Department of Physiology, S. Nijalingappa Medical College, Bagalkot - 587103, Karnataka, India (e-mail: dranitaherur@gmail.com).
\end{abstract}

\begin{abstract}
Keywords

- molecular genetics

- preeclampsial eclampsia

- vascular biology
\end{abstract}

Objective To assess the influence of oxidative stress on the gene expression of nitric oxide synthases (NOS 3 and NOS 2) and, hence, the cardiovascular responses in preeclampsia.

Methods This was a case control study in which patients with preeclampsia (PE group) and normal pregnancy controls (NP group) were included according to the guidelines of the American College of Obstetricians and Gynecologists (ACOG). The serum levels of malondialdehyde (MDA), total antioxidant capacity, and nitric oxide (NO) were estimated, and the heart rate and mean arterial pressure were recorded. The gene profiling of NOS3 and NOS2 was performed through real-time polymerase chain reaction (RT-PCR). The statistical analysis was performed using the Student $t$-test, and values of $p<0.05$ were considered statistically significant.

Results The serum levels of malondialdehyde were increased $(p<0.0001)$, and the total antioxidant capacity was reduced in the PE group $(p=0.034)$, indicating oxidative stress. In the PE group, the mean arterial pressure was significantly higher $(p<0.0001)$, but the serum levels of NO did not show a statistically significant reduction $(p=0.20)$. The gene expression profiling of NOS3 and NOS2 revealed a down regulation in the PE group by 8.49 and 51.05 times respectively.

Conclusion Oxidative stress may lead to endothelial dysfunction, which could result in increased mean arterial pressure. Nitric oxide may play a role in this mechanism, received

June 21, 2020

accepted

November 3, 2021

published online

January 31, 2022
DOI https://doi.org/

$10.1055 / \mathrm{s}-0042-1742313$ ISSN 0100-7203.
(C) 2022. Federação Brasileira de Ginecologia e Obstetrícia. All rights reserved.

This is an open access article published by Thieme under the terms of the Creative Commons Attribution License, permitting unrestricted use, distribution, and reproduction so long as the original work is properly cited. (https://creativecommons.org/licenses/by/4.0/)

Thieme Revinter Publicações Ltda., Rua do Matoso 170, Rio de Janeiro, RJ, CEP 20270-135, Brazil 


\section{Resumo}

\author{
Palavras-chave \\ - genética molecular \\ - pré- \\ eclâmpsia/eclâmpsia \\ - biologia vascular
}

but interactions with other vasoactive /biological substances cannot be overlooked, as the gene expression of NOS3 and NOS2 has been reduced.

Objetivo Avaliar a influência do estresse oxidativo na expressão genética das óxido nítrico sintases (nitric oxide synthases, NOS, em inglês; NOS 3 e NOS 2) e, consequentemente, nas respostas cardiovasculares na pré-eclâmpsia.

Métodos Este foi um estudo caso-controle no qual pacientes com pré-eclâmpsia (grupo PE) e controles com gravidez normal (grupo GN) foram incluídos de acordo com as diretrizes do American College of Obstetricians and Gynecologists (ACOG). Foram estimados os níveis séricos de malondialdeído (MDA) da capacidade antioxidante total, e de óxido nítrico (nitric oxide, NO, em inglês). A frequência cardíaca e a pressão arterial média foram registradas. O perfil genético da NOS3 e da NOS2 foi feito por reação em cadeia de polimerase em tempo real (real-time polymerase chain reaction, RT-PCR, em inglês). A análise estatística foi feita utilizando-se o teste $t$ de Student, e valores de $p<0,05$ foram considerados estatisticamente significativos.

Resultados Os níveis séricos de malondialdeído sérico estavam aumentados $(p<0,0001)$, e a capacidade antioxidante total, reduzida no grupo PE $(p=0,034)$, o que indicava estresse oxidativo. No grupo $\mathrm{PE}$, a pressão arterial média era significativamente maior $(p<0,0001)$, mas os níveis séricos de NO não demostraram redução estatisticamente significativa $(p=0,20)$. O perfil de expressão genética da NOS3 e da NOS2 revelou uma regulação negativa no grupo PE de 8,49 e 51,05 vezes, respectivamente.

Conclusão $O$ estresse oxidativo pode levar à disfunção endotelial, o que pode resultar em aumento da pressão arterial média. O NO pode desempenhar um papel neste mecanismo, mas as interações com outras substâncias vasoativas/biológicas não podem ser negligenciadas, uma vez que a expressão genética da NOS3 e da NOS2 foi reduzida.

\section{Introduction}

Normal pregnancy is marked by systemic inflammation, oxidative stress, and changes in angiogenic factors and vascular reactivity. This phenomenon is very much increased in pre-eclampsia (PE), with an impairment of compensatory mechanisms, eventually leading to vascular dysfunction. ${ }^{1}$ The pathophysiology of PE is not completely understood. Nitric oxide (NO) may be responsible for gestational vasodilation due to its vasodilator action. ${ }^{2}$ The production of NO from L-arginine is catalyzed by nitric oxide synthases (NOSs), which include neuronal NOS, endothelial NOS (eNOS/NOS3) and inducible NOS (iNOS/NOS2). ${ }^{3}$

Reduced uterine perfusion pressure (RUPP) and placental ischemia may lead to endothelial and cardiovascular dysfunction through increased production of cytokines, which may trigger endothelial dysfunction by decreasing the bioavailability of NO and increasing that of reactive oxygen species (ROS). ${ }^{4}$

The maternal vasculature is a major source of reactive oxygen and nitrogen species, which can interact to produce peroxynitrite, a powerful prooxidant that alters vascular function in PE. ${ }^{1}$ Preeclampsia increases oxidative stress in the placental and maternal systemic circulations. ${ }^{5}$

The expression of NOSs alters in PE; upregulation of eNOS expression has been demonstrated during normal pregnan$c y,{ }^{6}$ but the expressions of messenger ribonucleic acid
(mRNA) and protein for eNOS are decreased in endothelial cells in cases of PE. ${ }^{7}$

However, there is a dearth of literature highlighting the role of oxidative stress on NOS gene expressions and the impact of these on the systemic circulation. Hence, the present study aims to assess the influence of oxidative stress on NOS 3 and NOS 2 gene expressions and, hence, the cardiovascular responses in $\mathrm{PE}$.

\section{Methods}

This was a case-control study conducted in a tertiary care centre in North Karnataka, India. Clearance was obtained from the Ethics Committee at S. Nijalingappa Medical College, Bagalkot, Karnataka, India (SNMC/IECHSR/2017-18/A48/1.1). Informed consent was obtained from all the participants. The size of the sample would have to be 23 participants in each group, which was calculated using the OpenEpi software, based on a study by Madazli et al., $2002^{8}$ (the mean SOD between the groups was used), and 22 participants in each group, based on a study by Kashinakunti et al., $2010^{9}$ (the mean MDA levels between the groups were used). Hence, the sample size was rounded off to 30 participants in each group.

Primigravidas aged between 18 and 35 years with singleton pregnancies and diagnosed with PE according to the guidelines of the American College of Obstetricians and 
Gynecologists (ACOG) ${ }^{10}$ were included in the study as the cases (PE group). Pregnant women diagnosed with gestational hypertension or eclampsia according to the ACOG guidelines, and those with diabetes mellitus, history of systemic hypertension, and cardiovascular or renal diseases were excluded from the study.

Healthy primigravidas aged between 18 and 35 years with singleton pregnancies, matched for age and gestational week with the cases were included as controls (normal pregnancy [NP] group), and pregnant women with a history of diabetes mellitus, systemic hypertension, PE, and cardiovascular or renal diseases were excluded from the control group.

The required demographics were collected from the participants according to a predesigned proforma. They were clinically examined, and the findings were recorded. Gestational age was calculated from first trimester ultrasonography report and as per the ACOG guidelines. ${ }^{11}$ Blood pressure was recorded using a mercury sphygmomanometer (Diamond, Maharashtra, India). The heart rate was caculated from lead II of the electrocardiogram (ECG), which was recorded using Powerlab (AD instruments, Sidney, Australia). The blood samples were drawn from the antecubital vein following aseptic precautions. Whole blood $(2.5 \mathrm{~mL})$ was transferred to PAXgene (QIAgen, Venlo, Netherlands) ribonucleic acid (RNA) tubes for NOS gene expression by real-time polymerase chain reaction (RT-PCR). Another $2.5 \mathrm{~mL}$ of blood was converted into serum for the estimation of the serum levels of NO (enzyme-linked immunosorbent assay [ELISA] kit method) and serum malondialdehyde (MDA, using the thiobarbituric acid reactive substance [TBARS] method), and the total antioxidant capacity (ELISA kit method).

\section{Gene Expression Profiling}

Isolation of the total RNA from human whole blood was performed using the PAXGene RNA isolation kit and following the manufacturer instructions. The quality of the total RNA was checked by agarose gel (1.5\%) electrophoresis, and the gel was observed with an ultraviolet (UV) transilluminator (Cleaver Scientific, Rugby, Warwickshire, United Kingdom). Complementary deoxyribonucleic acid
(cDNA) was synthesised, and its quality was checked with agarose gel (1.5\%) electrophoresis with a standardized protocol.

\section{Expression Profiling of NOS3}

The gene expression profiling for NOS3 in samples from both the groups (NP and $\mathrm{PE}$ ) was analysed using forward primer 5 ' CTGGCTTTCCCTTCCAGAT 3' and reverse primer 5' CTTAATCTGGAAGGCCCCTC 3', along with the GAPDH gene as a positive control.

\section{Expression Profiling of NOS2}

The gene expression profiling for NOS2 in samples from both the groups (NP and PE) was analysed using forward primer 5' GATATCCCCCAGCCCTCAAGT 3' and reverse primer 5' GAGGCCCCAGTTTGAGAGAG 3', along with the Glyceraldehyde 3-phosphate dehydrogenase (GAPDH) gene as a positive control.

Each reaction was analysed in triplicate along with a negative control (without sample). Quantification cycles (Cq) values were recorded using the CFX Real-Time PCR(Bio-Rad, Hercules, CA, United States). The gene expressions of NOS3 and NOS2 were calculated using $2^{\wedge}-\Delta \Delta \mathrm{Cq}$ formula.

The serum levels of nitric oxide and total antioxidant capacity were estimated using ELISA kits as per the manufacturer's guidelines, and the serum levels of MDA were estimated by the TBARS method. ${ }^{12}$

\section{Statistical Analysis}

Data was analyzed with the Statistical Package for the Social Sciences (IBM SPSS Statistics for Windows, IBM Corp., Amonk, NY, United States) software, version 19.0, using the Student $t$-test, and values of $p<0.05$ were considered statistically significant.

\section{Results}

- Table 1 depicts the mean age and the gestational age of the mothers in both groups, and the results showed that there was no significant difference between them.

Table 1 Maternal and gestational ages in normal pregnancy and preeclampsia

\begin{tabular}{|c|c|c|c|c|}
\hline & $\begin{array}{l}\text { Normal pregnancy (NP) group } \\
(n=30)\end{array}$ & $\begin{array}{l}\text { Preeclampsia (PE) group } \\
(\mathrm{n}=30)\end{array}$ & t-value & $p$-value \\
\hline Maternal age (years) & $22.97 \pm 3.12$ & $22.67 \pm 3.83$ & 0.333 & 0.215 \\
\hline Gestational age (weeks) & $37.63 \pm 3.16$ & $36.10 \pm 4.29$ & 1.578 & 0.120 \\
\hline
\end{tabular}

Table 2 Oxidative stress markers in normal pregnancy and preeclampsia

\begin{tabular}{lllr}
\hline & $\begin{array}{l}\text { Normal pregnancy (NP) } \\
\text { group }(\mathbf{n}=30)\end{array}$ & $\begin{array}{l}\text { Preeclampsia (PE) group } \\
(\mathbf{n}=30)\end{array}$ & t-value \\
\hline $\begin{array}{l}\text { Serum malondialdehyde } \\
\text { (nmol/mL) }\end{array}$ & $2.50 \pm 0.42$ & $5.66 \pm 1.02$ & 12.682 \\
$\begin{array}{l}\text { Serum total } \\
\text { antioxidant capacity }(\mathrm{ng} / \mathrm{mL})\end{array}$ & $144.56 \pm 65.24$ & $112.37 \pm 48.36$ & 2.171 \\
\hline
\end{tabular}


Table 3 Cardiovascular responses in normal pregnancy and preeclampsia

\begin{tabular}{|c|c|c|c|c|}
\hline & $\begin{array}{l}\text { Normal pregnancy (NP) group } \\
(n=30)\end{array}$ & $\begin{array}{l}\text { Preeclampsia (PE) group } \\
(\mathrm{n}=30)\end{array}$ & t-value & $p$-value \\
\hline Systolic blood pressure $(\mathrm{mmHg})$ & $116.80 \pm 10.68$ & $154.07 \pm 17.10$ & 10.122 & 0.0001 \\
\hline Diastolic blood pressure $(\mathrm{mmHg})$ & $73.40 \pm 8.60$ & $100.20 \pm 8.64$ & 12.044 & 0.0001 \\
\hline Mean arterial pressure $(\mathrm{mmHg})$ & $87.87 \pm 8.19$ & $118.16 \pm 10.95$ & 12.134 & 0.0001 \\
\hline Heart rate (beats/min) & $93.10 \pm 9.50$ & $92.33 \pm 12.04$ & 0.274 & 0.785 \\
\hline
\end{tabular}

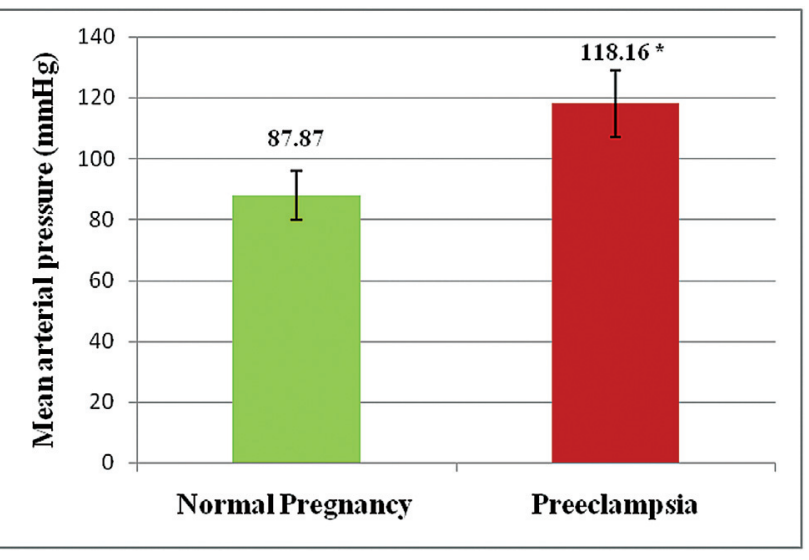

Fig. 1. Mean arterial pressure of patients with preeclampsia.

A significant oxidative stress was noted in the PE group by an increase in the serum levels of MDA and a decrease in total antioxidant capacity (-Table $\mathbf{2}$ ).

The systolic, diastolic, and mean arterial pressures (in $\mathrm{mmHg}$ ) were found to be significantly higher, by $37.26,26.80$, and 30.28 respectively in the PE group (-Table $\mathbf{3}$ ) (-Figure $\mathbf{1}$ ). The mean heart rate was slightly lower in the PE group as compared to the NP group, but not statistically significant.

There was no significant difference in the serum levels of NO in both the groups (NP group: $35.43 \pm 20.37 \mu \mathrm{mol} / \mathrm{L}$; PE group: $30.09 \pm 10.08 \mu \mathrm{mol} / \mathrm{L} ; \mathrm{t}=1.285 ; p=0.204)$. The gene expression profiling was only performed in 25 suitable samples from each group. The mean difference in the $\mathrm{Cq}$ values of NOS3 in the RT-PCR, as against the positive control (GAPDH), was higher in the PE compared to the NP group. Consequently, when the gene expression of NOS3 was calcu- lated, a down-regulation was observed in the PE group compared to the NP group by a difference of 8.49 times (-Table 4).

The mean difference in the Cq values of NOS2 in the RTPCR as against the positive control (GAPDH) was higher in the PE group; consequently, when the gene expression of NOS2 was calculated, a down-regulation was oberved in the PE group compared to the NP group, by a difference of 51.05 times (-Table 5).

\section{Discussion}

Pregnancy is a state of oxidative stress due to increased metabolism in the mother and the metabolic activity of the placenta. The ischemic or poorly-perfused placenta resulting from inadequate trophoblast invasion exhibits increased oxidative stress in PE, evident from the increased formation of free radicals, lipid peroxides, and reduced antioxidant defenses. ${ }^{1,13}$ The mean plasma levels of MDA were higher, and the levels of glutathione and superoxide dismutase were significantly lower in PE. ${ }^{8,14}$ In the present study, we also observed an increase in the oxidative stress marker, serum MDA, which was accompanied by a decrease in the serum levels of total antioxidant capacity. In a study by Lee et al., ${ }^{15}$ the neutrophils from women with PE produced significantly more ROS than those of the agematched normotensive controls. Antioxidants protect against lipid peroxidation mediated by free radical. Normal pregnancy is associated with an increase in oxidative stress and lipid peroxidation, but antioxidant protection also increases. ${ }^{16}$ In $\mathrm{PE}$, there is still a further increase in lipid peroxides as well as an insufficient increase in antioxidants to combat the increase in oxidative stress and lipid peroxidation. ${ }^{17}$ An increase in oxidative stress and a decrease in antioxidants may be

Table 4 Gene expression of endothelial nitric oxide synthase (NOS3) by real-time polymerase chain reaction

\begin{tabular}{|c|c|c|c|c|c|}
\hline & $\begin{array}{l}\text { Cq of the } \\
\text { sample (NOS3) } \\
1\end{array}$ & $\begin{array}{l}\text { Cq of the positive } \\
\text { control } \\
\text { (GAPDH) } \\
2\end{array}$ & $\begin{array}{l}\Delta \mathrm{Cq} \\
1-2\end{array}$ & $\begin{array}{l}\Delta \Delta \mathrm{Cq} \\
\text { [ } \Delta \mathrm{cq} \text { of sample - } \\
\text { average } \Delta \mathrm{cq} \text { of } \\
\text { control group }\}\end{array}$ & $2^{\wedge}-\Delta \Delta C q$ \\
\hline $\begin{array}{l}\text { Normal pregnancy } \\
\text { group } \\
(\mathrm{n}=25)\end{array}$ & $23.14 \pm 3.43$ & $15.11 \pm 1.82$ & $7.96 \pm 3.30$ & $0.32 \pm 3.63$ & 14.63 \\
\hline $\begin{array}{l}\text { Preeclampsia } \\
\text { group } \\
(n=25)\end{array}$ & $24.73 \pm 2.56$ & $15.63 \pm 3.19$ & $9.10 \pm 2.74$ & $1.14 \pm 2.74$ & 6.14 \\
\hline
\end{tabular}

Abbreviations: Cq: Quantification cycles; GAPDH: Glyceradehyde 3-Phosphate dehydrogenase. 
Table 5 Gene expression of inducible nitric oxide synthase (NOS2) by real-time polymerase chain reaction

\begin{tabular}{lllll}
\hline & $\begin{array}{l}\text { Cq of the sample } \\
\text { (NOS2) }\end{array}$ & $\begin{array}{l}\text { Cq of the positive } \\
\text { control } \\
\text { (GAPDH) }\end{array}$ & $\Delta$ Cq & $\begin{array}{l}\Delta \Delta \text { Cq } \\
\text { [cq of sample }- \text { average } \\
\Delta \text { cq of control group] }\end{array}$ \\
\hline $\begin{array}{l}\text { Normal } \\
\text { pregnancy } \\
\text { group } \\
(\mathrm{n}=25)\end{array}$ & $26.63 \pm 1.79$ & $16.47 \pm 3.34$ & $10.15 \pm 3.49$ & $0.004 \pm 3.49$ \\
$\begin{array}{l}\text { Preeclampsia } \\
\text { group }\end{array}$ & $27.40 \pm 1.27$ & $16.24 \pm 2.59$ & $11.16 \pm 2.42$ & $10.38 \pm 3.19$ \\
$(\mathrm{n}=25)$ & & & & \\
\hline
\end{tabular}

Abbreviations: Cq: Quantification cycles; GAPDH: Glyceradehyde 3-Phosphate dehydrogenase.

responsible for the subsequent pathophysiology of PE. However, in one study, ${ }^{18}$ supplementation with antioxidants like vitamins $\mathrm{C}$ and $\mathrm{E}$ did not show any difference in terms of reduction in the incidence of $\mathrm{PE}$.

Reactive oxygen species seem to play an important role in the endothelial dysfunction associated with PE. Oxidative stress induces the adhesion of leukocytes and platelets to the endothelium as well as the release of cytokines and anti-angiogenic factors, which suggest an inflammatory state, as observed in PE.

Vascular endotheliosis, an increase in the inflammatory vasoconstrictors, and a decrease in the nitric oxide may have been responsible for an increase in the mean arterial pressure, as observed in the present study. A previous study ${ }^{19}$ also revealed an increment of $13.3 \%$ in the mean arterial pressure in PE as against 5.2\% in the normotensive group. But the decrease in serum NO was not statistically significant. Similarly, studies show an increase in NO production during pregnancy, and a decrease during $\mathrm{PE}^{3}$ or an increase in NO levels in $\mathrm{PE},{ }^{20}$ or no change in NO levels. ${ }^{21}$

Through the intrinsic synthesis of NO, eNOS is expressed constitutively in the vascular endothelium and maintains the vascular tone, hence inhibiting the adhesion of leukocytes and platelets to the endothelium and preventing the proinflammatory state. ${ }^{22}$ Increased ROS production seems to suppress the expression and function of eNOS. ${ }^{23}$ In the present study, a decrease in the expression of NOS3 was observed. Reduced expression of eNOS and oxidative stress could play a role in the pathology of $\mathrm{PE}$, both in the placenta and in the maternal endothelium. ${ }^{24}$ Increased ROS leads to lipid peroxidation, which increases the levels of MDA, as observed in the present study, and lipid peroxidation also decreases the calcium/adenosine triphosphatase (ATPase) (ATPase) activity, which in turn, may decrease the eNOS expression, as it is calcium dependent. ${ }^{14}$

Oxidative stress leads to up-regulation of proinflammatory genes like iNOS, which is stimulated in a proinflammatory condition, such as NP, and produces a temporary excess of NO, maybe through activation of proinflammatory transcription factor nuclear factor kappa-light-chain-enhancer of activated $\mathrm{B}$ cells (NF-kB). ${ }^{18}$ The literature also reports that the expression of iNOS is decreased, and that of eNOS is increased, as a result of the compensatory mechanism at a later stage in PE. ${ }^{14}$ In the present study, the gene expressions of iNOS or NOS2, as well as of eNOS or NOS 3, were reduced.
But our understanding is that a decrease in antioxidants as the cause has not been well supported, as supplementation of vitamins $\mathrm{C}$ and $\mathrm{E}$ failed to produce any positive response in PE. Hence, other mechanisms involved have to be contemplated. In PE, the inflammatory condition and excessive oxidative stress may stimulate the production of heat shock proteins (HSPs), which may suppress iNOS; and the role of VEGF, s-Flt or HIF-alpha should also be considered. The exact mechanisms underlying the pathophysiology of PE need to be researched in depth for the proper understanding, diagnosis, and therapeutic options. Although the gene expression was done in the present study, the quantification of the expression of proteins was not feasible with the available resources. A follow-up study on PE patients with serial NOS2 and NOS 3 gene expression is contemplated. The authors also intend to study the role of HSPs in PE.

\section{Conclusion}

Oxidative stress may lead to endothelial dysfunction, which could result in increased mean arterial pressure, and NO may play a role in this mechanism, but interactions with other vasoactive /biological substances cannot be overlooked, as the gene expressions of NOS3 and NOS2 have been reduced.

\section{Contributions}

All the authors have contributed equally to this paper, namely to the conception and design, data collection or analysis, and interpretation of data, writing of the article, and review of the intellectual content. Therefore, all authors approved the final version to be published.

\section{Conflict of Interests}

The authors have no conflict of interests to declare.

\section{References}

1 Myatt L, Webster RP. Vascular biology of preeclampsia. J Thromb Haemost. 2009;7(03):375-384. Doi: 10.1111/j.1538-7836.2008. 03259.x

2 Sladek SM, Magness RR, Conrad KP. Nitric oxide and pregnancy. Am J Physiol. 1997;272(2 Pt 2):R441-R463. Doi: 10.1152/ ajpregu.1997.272.2.R441

3 Choi JW, Im MW, Pai SH. Nitric oxide production increases during normal pregnancy and decreases in preeclampsia. Ann Clin Lab Sci. 2002;32(03):257-263 
4 Gilbert JS, Ryan MJ, LaMarca BB, Sedeek M, Murphy SR, Granger JP. Pathophysiology of hypertension during preeclampsia: linking placental ischemia with endothelial dysfunction. Am J Physiol Heart Circ Physiol. 2008;294(02):H541-H550. Doi: 10.1152/ ajpheart.01113.2007

5 Burton GJ, Yung HW, Cindrova-Davies T, Charnock-Jones DS. Placental endoplasmic reticulum stress and oxidative stress in the pathophysiology of unexplained intrauterine growth restriction and early onset preeclampsia. Placenta 2009;30 Suppl A:S438. Doi: 10.1016/j.placenta.2008.11.003

6 Sutton EF, Gemmel M, Powers RW. Nitric oxide signaling in pregnancy and preeclampsia. Nitric Oxide. 2020;95:55-62. Doi: 10.1016/j.niox.2019.11.006

7 Wang Y, Gu Y, Zhang Y, Lewis DF. Evidence of endothelial dysfunction in preeclampsia: decreased endothelial nitric oxide synthase expression is associated with increased cell permeability in endothelial cells from preeclampsia. Am J Obstet Gynecol. 2004;190(03):817-824. Doi: 10.1016/j.ajog.2003.09.049

8 Madazli R, Benian A, Aydin S, Uzun H, Tolun N. The plasma and placental levels of malondialdehyde, glutathione and superoxide dismutase in pre-eclampsia. J Obstet Gynaecol. 2002;22(05): 477-480. Doi: 10.1080/0144361021000003573

9 Kashinakunti SV, Sunitha H, Gurupadappa K, Shankarprasad DS, Suryaprakash G, Ingin JB. Lipid peroxidation and antioxidant status in preeclampsia. Al Ameen J Med Sci. 2010;3(01):38-41

10 American College of Obstetricians and Gynecologists. ACOG Practice Bulletin No. 202: gestational hypertension and preeclampsia. Obstet Gynecol. 2019;133(01):1. Doi: 10.1097/AOG.0000000000003018

11 American College of Obstetricians and Gynecologists. Committee Opinion No. 700: methods for estimating the due date. Obstet Gynecol. 2017;129(05):e150-e154. Doi: 10.1097/AOG.0000000000002046

12 Bird RP, Draper HH. Comparative studies on different methods of malonaldehyde determination. Methods Enzymol. 1984; 105:299-305. Doi: 10.1016/s0076-6879(84)05038-2

13 Roberts JM, Hubel CA. The two stage model of preeclampsia: variations on the theme. Placenta 2009;30 Suppl A:S32-7. Doi: 10.1016/j.placenta.2008.11.009

14 Napolitano M, Miceli F, Calce A, Vacca A, Gulino A, Apa R, et al. Expression and relationship between endothelin-1 messenger ribonucleic acid (mRNA) and inducible/endothelial nitric oxide synthase mRNA isoforms from normal and preeclamptic placentas. J Clin Endocrinol Metab. 2000;85(06):2318-2323. Doi: $10.1210 /$ jcem.85.6.6623

15 Lee VM, Quinn PA, Jennings SC, Ng LL. Neutrophil activation and production of reactive oxygen species in pre-eclampsia. J Hyper- tens. 2003;21(02):395-402. Doi: 10.1097/00004872-20030200000032

16 Wang YP, Walsh SW, Guo JD, Zhang JY. Maternal levels of prostacyclin, thromboxane, vitamin $\mathrm{E}$, and lipid peroxides throughout normal pregnancy. Am J Obstet Gynecol. 1991;165 (6 Pt 1):1690-1694. Doi: 10.1016/0002-9378(91)90016-k

17 Wang Y, Walsh SW. Antioxidant activities and mRNA expression of superoxide dismutase, catalase, and glutathione peroxidase in normal and preeclamptic placentas. J Soc Gynecol Investig. 1996; 3(04):179-184

18 Roberts JM, Myatt L, Spong CY, Thom EA, Hauth JC, Leveno KJ, et al; Eunice Kennedy Shriver National Institute of Child Health and Human Development Maternal-Fetal Medicine Units Network. Vitamins $C$ and $E$ to prevent complications of pregnancy-associated hypertension. N Engl J Med. 2010;362(14):1282-1291. Doi: 10.1056/NEJMoa0908056

19 Mayrink J, Souza RT, Feitosa FE, Rocha Filho EA, Leite DF, Vettorazzi J, et al; Preterm SAMBA study group. Mean arterial blood pressure: potential predictive tool for preeclampsia in a cohort of healthy nulliparous pregnant women. BMC Pregnancy Childbirth. 2019;19(01):460. Doi: 10.1186/s12884-0192580-4

20 Baker PN, Davidge ST, Roberts JM. Plasma from women with preeclampsia increases endothelial cell nitric oxide production. Hypertension. 1995;26(02):244-248. Doi: 10.1161/01. hyp.26.2.244

21 Diejomaoh FM, Omu AE, Al-Busiri N, Taher S, Al-Othman S, Fatinikun $\mathrm{T}$, et al. Nitric oxide production is not altered in preeclampsia. Arch Gynecol Obstet. 2004;269(04):237-243. Doi: 10.1007/s00404-002-0465-6

22 Matsubara K, Higaki T, Matsubara Y, Nawa A. Nitric oxide and reactive oxygen species in the pathogenesis of preeclampsia. Int J Mol Sci. 2015;16(03):4600-4614. Doi: 10.3390/ijms16034600

23 Farrow KN, Lakshminrusimha S, Reda WJ, Wedgwood S, Czech L, Gugino SF, et al. Superoxide dismutase restores eNOS expression and function in resistance pulmonary arteries from neonatal lambs with persistent pulmonary hypertension. Am J Physiol Lung Cell Mol Physiol. 2008;295(06):L979-L987. Doi: 10.1152/ ajplung.90238.2008

24 Shaheen G, Jahan S, Ain QU, Ullah A, Afsar T, Almajwal A, et al. Placental endothelial nitric oxide synthase expression and role of oxidative stress in susceptibility to preeclampsia in Pakistani women. Mol Genet Genomic Med. 2020;8(01):e1019. Doi: $10.1002 /$ mgg3.1019 